\title{
Diagnostic accuracy of a panel of immunohistochemical and molecular markers to distinguish Merkel cell carcinoma from other neuroendocrine carcinomas
}

\author{
Thibault Kervarrec ${ }^{1,2,3} \cdot$ Anne Tallet ${ }^{4} \cdot$ Elodie Miquelestorena-Standley ${ }^{1} \cdot$ Roland Houben $^{3}{ }^{3} \cdot$ David Schrama $^{3}$. \\ Thilo Gambichler $^{5}$ - Patricia Berthon ${ }^{2}$ - Yannick Le Corre ${ }^{6}$. Ewa Hainaut-Wierzbicka ${ }^{7}$. Francois Aubin ${ }^{8}$. \\ Guido Bens $^{9} \cdot$ Flore Tabareau-Delalande $^{10} \cdot$ Nathalie Beneton $^{11} \cdot$ Gaëlle Fromont $^{12} \cdot$ Flavie Arbion $^{12}$. \\ Emmanuelle Leteurtre $^{13} \cdot$ Antoine Touzé $^{2} \cdot$ Mahtab Samimi $^{2,14} \cdot$ Serge Guyétant $^{1,2}$
}

Received: 14 July 2018 / Revised: 2 September 2018 / Accepted: 3 September 2018 / Published online: 22 October 2018

(c) United States \& Canadian Academy of Pathology 2018

\begin{abstract}
Merkel cell carcinoma is a rare neuroendocrine carcinoma of the skin mostly induced by Merkel cell polyomavirus integration. Cytokeratin 20 (CK20) positivity is currently used to distinguish Merkel cell carcinomas from other neuroendocrine carcinomas. However, this distinction may be challenging in CK20-negative cases and in cases without a primary skin tumor. The objectives of this study were first to evaluate the diagnostic accuracy of previously described markers for the diagnosis of Merkel cell carcinoma and second to validate these markers in the setting of difficult-todiagnose Merkel cell carcinoma variants. In a preliminary set $(n=30)$, we assessed optimal immunohistochemical patterns (CK20, thyroid transcription factor 1 [TTF-1], atonal homolog 1 [ATOH1], neurofilament [NF], special AT-rich sequencebinding protein 2 [SATB2], paired box protein 5, terminal desoxynucleotidyl transferase, CD99, mucin 1, and Merkel cell polyomavirus-large $\mathrm{T}$ antigen) and Merkel cell polyomavirus load thresholds (real-time PCR). The diagnostic accuracy of each marker was then assessed in a validation set of 103 Merkel cell carcinomas (9 CK20-negative cases and 15 cases without a primary skin tumor) and 70 extracutaneous neuroendocrine carcinoma cases. The most discriminant markers for a diagnosis of Merkel cell carcinoma were SATB2, NF expression, and Merkel cell polyomavirus DNA detection (positive likelihood ratios: 36.6, 44.4, and 28.2, respectively). Regarding Merkel cell carcinoma variants, cases without a primary skin tumor retained a similar immunohistochemical profile and CK20-negative tumors displayed a different profile (decrease frequency of NF and SATB2 expression), but Merkel cell polyomavirus DNA remained detected (78\% of cases by qPCR). Moreover, 8/9 (89\%) CK20-negative Merkel cell carcinoma cases but only 3/61 (5\%) CK20-negative extracutaneous neuroendocrine cases were positive for at least one of these markers. In conclusion, detection of SATB2 and NF expression and Merkel cell polyomavirus DNA helps distinguish between Merkel cell carcinoma classical and variant cases and extracutaneous neuroendocrine carcinomas.
\end{abstract}

These authors contributed equally: A. Tallet, E. MiquelestorenaStandley

These authors jointly supervised this work: M. Samimi, S. S. Guyétant

Electronic supplementary material The online version of this article (https://doi.org/10.1038/s41379-018-0155-y) contains supplementary material, which is available to authorized users.

Serge Guyétant

serge.guyetant@univ-tours.fr

Extended author information available on the last page of the article.

\section{Introduction}

Merkel cell carcinoma is a rare primary carcinoma of the skin with both epithelial and neuroendocrine differentiation [1]. This tumor occurs essentially in older or immunosuppressed people and features aggressive behavior, with an overall 5-year survival estimated at $40 \%$. In 2008, Feng et al. discovered the genome of a new polyomavirus in Merkel cell carcinoma tumors [2]. Indeed, genomic integration of the Merkel cell polyomavirus is observed in about $80 \%$ of Merkel cell carcinoma cases and is associated with mutations of the viral sequence that lead to truncation of the large $\mathrm{T}$ antigen (LTAg) $[2,3]$. Besides the truncated 
LTAg, small $\mathrm{T}$ antigen is the only viral protein generally expressed in Merkel cell carcinoma; the expression of capsid proteins is frequently lost [4] and both T-antigens are considered the main oncogenic triggers in Merkel cell polyomavirus-positive Merkel cell carcinomas [5, 6].

Under microscopy examination, Merkel cell carcinoma appears as an undifferentiated, round, blue-cell neoplasm of the skin with high-grade neuroendocrine carcinoma features [1]. Immunohistochemical analysis reveals the expression of neuroendocrine markers, associated in most cases with cytokeratin 20 (CK20). Indeed, CK20 positivity and negativity for thyroid transcription factor 1 (TTF-1) are routinely used to distinguish Merkel cell carcinoma from metastasis of extracutaneous neuroendocrine carcinoma [1, 7]. However, Merkel cell carcinoma variants lacking CK20 expression $[8,9]$ or expressing TTF-1 [10] are observed in about $10 \%$ of cases. Furthermore, CK20 positivity has been reported in extracutaneous neuroendocrine carcinomas [7, 11], which led the World Health Organization to recommend a systematic whole-body imaging work-up in all suspected Merkel cell carcinoma cases to exclude metastasis of extracutaneous primary neuroendocrine carcinomas [1]. In addition, Merkel cell carcinoma may present as an isolated lymph node tumor without a detectable primary skin tumor $[12,13]$ and be misdiagnosed as lymph node metastasis of extracutaneous neuroendocrine carcinoma [13].

During the past few years, several immunohistochemical and molecular markers have been suggested as additional candidates for a positive diagnosis of Merkel cell carcinoma. Indeed, besides the expression of CK20 and neuroendocrine markers, Merkel cell carcinoma was found to express Merkel cell markers (e.g., neurofilament [NF] [14, 15], atonal homolog 1 [ATOH1] [16], and special ATrich sequence-binding protein 2 [SATB2] [17]), lymphoid markers $[18,19]$ (e.g., paired box protein 5 [PAX5] and terminal desoxynucleotidyl transferase [TdT]), CD99 [20], and the cell surface-associated mucin 1 (MUC1) [21]. Because of Merkel cell polyomavirus-driven oncogenesis, detection of Merkel cell polyomavirus by immunochemistry $[22,23]$ and molecular procedures [2] has been suggested for Merkel cell carcinoma diagnosis. However, such markers were frequently assessed in small cohorts and without controlling for the main differential confounders of Merkel cell carcinoma, represented by neuroendocrine carcinoma metastasis. Therefore we have no comprehensive data on the accuracy of these markers for a positive diagnosis of Merkel cell carcinoma.

The aim of this study was to compare the diagnostic performance of these markers for distinguishing Merkel cell carcinoma from extracutaneous neuroendocrine carcinoma, with a focus on difficult-to-diagnose Merkel cell carcinoma variants such as CK20-negative cases and
Merkel cell carcinoma of the lymph node without a skin primary tumor.

\section{Methods}

\section{Design and settings}

Merkel cell carcinoma cases were selected from a historical/ prospective multicentric French cohort of patients with a diagnosis of Merkel cell carcinoma established between 1998 and 2017 (Local Ethics Committee in Human Research, Tours, France; no. ID RCB2009-A01056-51). Inclusion criteria for the cohort were previously described $[24,25]$. Briefly, tumors with available formalin-fixed and paraffin-embedded tissue samples were included as Merkel cell carcinoma cases if they displayed a compatible morphology, with the combination of CK20 positivity and at least one neuroendocrine marker (synaptophysin and chromogranin A) [1] or in the absence of CK20 positivity, expression of at least two neuroendocrine markers together with absence of deep neuroendocrine carcinoma confirmed by imaging work-up (CT scan or 18-FDG-TEP scan). Merkel cell carcinoma without a skin primary tumor cases were identified as previously described [13] as lymph node metastasis revealing the cancer, with no previous history of cutaneous Merkel cell carcinoma or deep neuroendocrine carcinoma and no evidence of cutaneous or extracutaneous primary neuroendocrine carcinoma after work-up consisting of cutaneous physical examination and imaging (CT scan and/or 18-FDG-TEP scan).

All extracutaneous neuroendocrine carcinomas registered between 1999 and 2017 in one department of pathology (Tours, France) were reviewed by using the following inclusion criteria: extracutaneous primary tumor, surgical biopsy or resection with available formalin-fixed and paraffin-embedded samples, high-grade and/or poorly differentiated features on pathological examination-classified as small-cell neuroendocrine carcinoma, large-cell neuroendocrine carcinoma, or mixed adenoneuroendocrine carcinoma-as well as immunohistochemical expression of pancytokeratin AE1-AE3 and at least two of the four following makers: chromogranin A, synaptophysin, CD56, and TTF-1 [26, 27].

The above inclusion criteria were considered the reference standards [28] for classification of Merkel cell carcinoma and neuroendocrine carcinoma.

\section{Clinical data}

Age, sex, and location of the primary tumor were collected from patient files. In addition, American Joint Committee on Cancer stage at the time of diagnosis, immune 
suppression (HIV infection, organ transplant recipients, hematological malignancies) [29] and follow-up data were collected for Merkel cell carcinoma patients.

\section{Tissue microarray and immunochemistry}

All Merkel cell carcinoma and neuroendocrine carcinoma samples were included in a tissue microarray. Central intratumor areas without necrosis were selected on hematoxylin phloxin saffron (HPS)-stained sections to exclude non-specific staining. The selected areas were extracted by using a 1-mm tissue core, and cores were mounted in triplicate on the tissue microarray by using a semi-motorized tissue array system (MTA booster OI v2.00, Alphelys). Immunohistochemical staining for CK20, TTF-1, NF, PAX5, TdT, and CD99 involved using a BenchMark XT Platform as instructed. Staining was performed manually for ATOH1 [16], MUC1 [30], and CM2B4 [5] as described. Antibodies and dilutions are in Supplemental Method S1.

\section{Interpretation of immunohistochemical staining}

The staining of immunohistochemical markers was evaluated independently by two pathologists (EMS, TK) who were blinded to the clinical data, and discordant cases were reviewed together. The interpretation of immunohistochemistry (staining categories) was as follows: CK20 [1] and TTF-1 [10] staining was classified binarily as positive or negative, and CK20-negative cases detected on tissue microarray were confirmed by overall slide staining [31]; NF [15], and CD99 [20] staining was classified as negative, diffuse, or paranuclear dot pattern positive; ATOH1 [16], SATB2 [17], PAX5 [19], and MUC-1 [21] staining was classified by using a semiquantitative score: 0: lack of staining, 1: low/moderate or heterogenous expression, 2: diffuse, strong, and homogenous staining identified by low magnification $(\times 5)$. Only cases with nuclear staining were classified as positive for TdT [32]. A semiquantitative Allred score was used for evaluating CM2B4 (LTAg of Merkel cell polyomavirus); scores $>2$ were considered Merkel cell polyomavirus-positive tumors, as descibed [22]. Representative illustrations of immunostainings are in Supplemental Method S1.

\section{Detection and quantification of Merkel cell polyomavirus DNA}

Detection and quantification of Merkel cell polyomavirus DNA were performed by a biologist (AT) who was blinded to the clinical and immunohistochemical data. Genomic DNA was isolated from tissue samples by use of the Maxwell 16 Instrument (Promega) with the Maxwell 16 formalin-fixed and paraffin-embedded Plus LEV DNA purification kit (Promega). LTAg real-time PCR assay was performed as described [23]. Briefly, 50 ng DNA was mixed with $0.2 \mu \mathrm{M}$ primers (Supplemental Method S2), 0.1 $\mu \mathrm{M}$ DNA probe and Mix Life technologies (Applied) GoTaq Probe real-time PCR Master Mix 2× (Promega) in a final volume of $20 \mu \mathrm{l}$. PCR reactions involved use of the LightCycler 480 II platform (Roche) with an initial denaturation at $95^{\circ} \mathrm{C} \times 2 \mathrm{~min}$, followed by 45 cycles at $95^{\circ} \mathrm{C} \times$ $15 \mathrm{~s}$ and $58^{\circ} \mathrm{C} \times 60 \mathrm{~s}$. Normalization was with albumin as the reference gene and the Waga Merkel cell carcinoma cell line (RRID:CVCL_E998) included as a control. The $\Delta \mathrm{Ct}$ method was used for quantification and results expressed as number of Merkel cell polyomavirus copies/cells. As negative controls, 37 non-Merkel cell carcinoma skin tumors (18 basal cell carcinomas, 9 squamous cell carcinomas, and 10 melanomas) were included, with no amplification observed in these cases.

\section{Statistical analysis}

Continuous data are described with median (Q1-Q3) and categorical data with number (\%) of interpretable cases. Categorical data were compared by two-tailed Fisher's exact test. $P<0.05$ was considered statistically significant. Diagnostic accuracy of index tests was determined in accordance with the STARD guidelines [28]. The inclusion criteria described above (Methods section, data and settings criteria) were considered the reference standards. Categories and thresholds of index tests were determined with a preliminary set of 30 cases. The diagnostic accuracy of index tests was compared with the reference standard by using the positive likelihood ratio as a measure of accuracy combining sensitivity and specificity. Index tests with positive likelihood ratio $>10$ were considered efficient [33]. Only markers with efficient diagnostic accuracy (positive likelihood ratio >10) were considered for further analyses (validation step, subgroup analysis between classical and variant Merkel cell carcinomas and CK20-negative neuroendocrine carcinoma setting). Statistical analysis involved use of XL-Stat-Life (Addinsoft, Paris, France).

\section{Results}

\section{Patient characteristics}

Among the Merkel cell carcinoma cohort, 118 cases were included in this study (Fig. 1). Median age was 78 years (Q1-Q3: 70-84) and sex ratio was 1.35 (F/M: 66/49). Immunosuppression was identified in $13 \%$ of cases $(n=11 /$ 83). Tumors were diagnosed at American Joint Committee on Cancer stages I, II, III, and IV in 31, 26, 38, and 5\% of cases, respectively. Most common primary tumor sites were 
Fig. 1 Flow of cases in the 1, SATB2, special AT-rich sequence-binding protein $2, \mathrm{NF}$ neurofilament, PAX5 paired box protein 5 , TdT terminal deoxynucleotidyl transferase, MUC1 cell surface-associated mucin 1. (*) cases with insufficient data for determination of the primary site (cutaneous or superficial lymph node location) study. ATOH1 atonal homolog

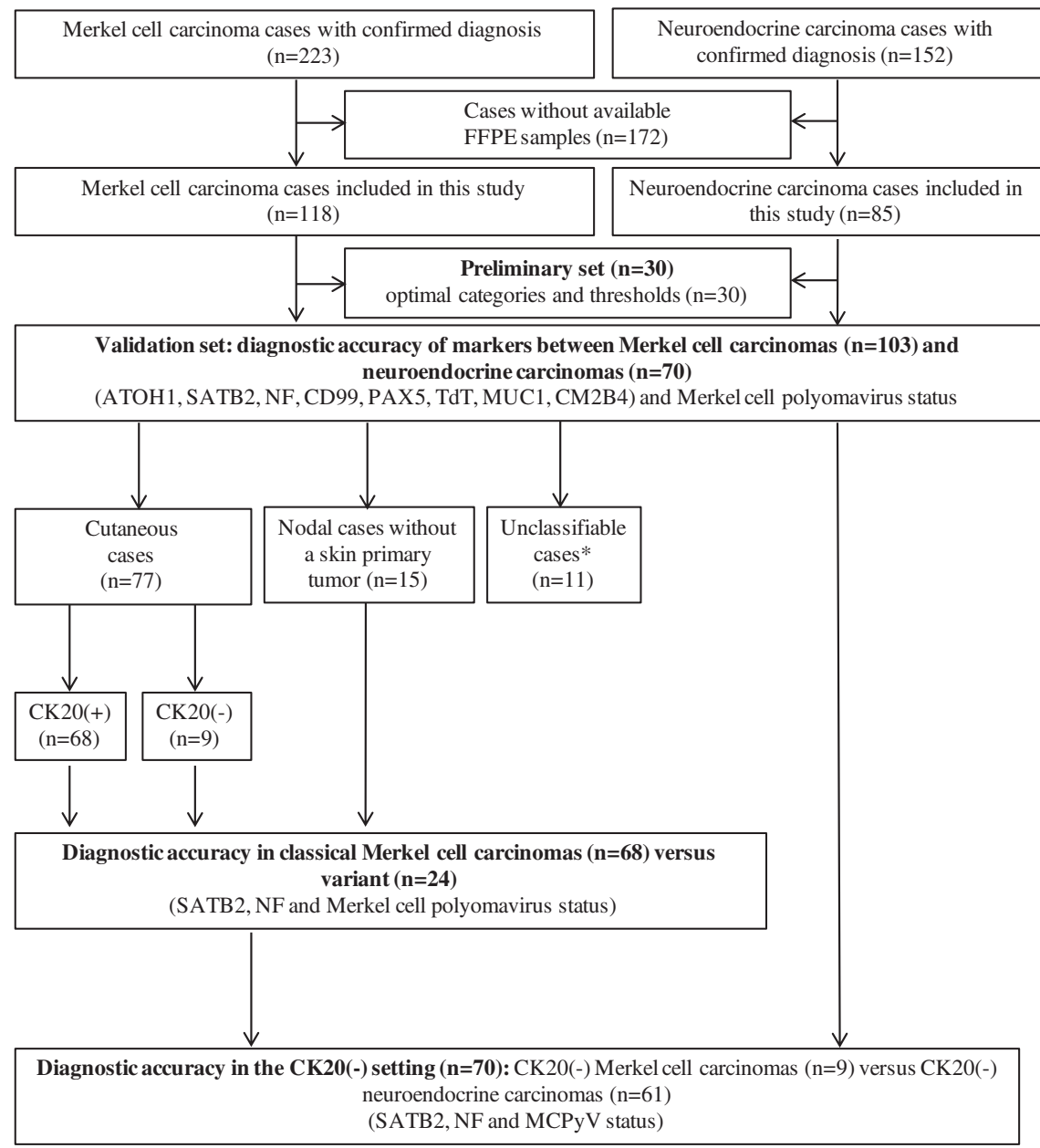

lower limbs (39\%) and head or neck (32\%). Follow-up data were available for 85 Merkel cell carcinoma cases. Median duration of follow up was 16 months (ranges 1-209), and 34 recurrences and 30 deaths were reported during follow up. Fifteen cases (14\%) were Merkel cell carcinomas without a skin primary tumor, $9(8 \%)$ were CK20-negative cutaneous Merkel cell carcinomas, and 83 (78\%) were CK20-positive cutaneous Merkel cell carcinomas. Thirteen cases (12\%) showed TTF-1 expression. In 11 cases, clinical and imaging data did not allow for identification of the primary tumor site (skin or lymph node) and the cases were excluded from subgroup analysis (Fig. 1).

Among extracutaneous neuroendocrine carcinoma cases that met inclusion criteria (Fig. 1), median age was 65 (Q1-Q3: 55-72) and sex ratio 1.9 (F/M: 56/29). Primary tumor sites were lung $(n=52,61 \%)$ and digestive $(n=22$, $26 \%)$, urologic $(n=7,8 \%)$, and gynecologic tract $(n=4$, $5 \%)$. The histological subtype was small-cell neuroendocrine carcinoma in $49 \%$ of cases $(n=42)$, large-cell neuroendocrine carcinoma in $47 \% \quad(n=40)$ and mixed adenoneuroendocrine carcinomas in $4 \%(n=3)$. Overall, 4 $(5 \%)$ and $45(58 \%)$ cases showed expression of CK20 and TTF-1, respectively.
Detailed immunohistochemical profiles of all Merkel cell carcinoma and neuroendocrine carcinoma cases by site of primary tumor and histological subtype are in supplemental Data S1.

\section{Preliminary step: determining optimal categories and thresholds of index tests}

Because several immunohistochemical markers were classified in three categories (semiquantitative score or expression by pattern) and lack of a consensual threshold for Merkel cell polyomavirus real-time PCR, optimal categories for a positive diagnosis of Merkel cell carcinoma versus neuroendocrine carcinoma were determined in an exploratory set of 30 cases. Fifteen Merkel cell carcinoma cases were randomly selected among the CK20-positive cutaneous Merkel cell carcinoma cases, considered the most representative, and compared with 15 neuroendocrine carcinoma cases from various anatomic sites randomly selected in each category ( 8 lung and 4 digestive, 2 urologic and 1 gynecologic tract). The detailed phenotype of these cases and representative illustrations of scoring are in supplemental Data S2-S3. In this preliminary analysis, NF and 
CD99 "dot staining"; ATOH1, SATB2, and MUC1 high and diffuse staining ("score 2") and Pax5 positivity ("scores 1-2") showed optimal accuracy for a positive diagnosis of Merkel cell carcinoma (see Supplemental Data S2) and were then assessed in the validation step.

The optimal positive threshold of real-time PCR (Merkel cell polyomavirus copies/cell $=1.2$ ) for a positive diagnosis of Merkel cell carcinoma was determined by the area under the receiver operating characteristic curve (AUC: 0.962; sensitivity: 0.93 (95\% confidence interval [CI] 0.66-1; specificity: 1 (95\% CI: 0.757-1) (Supplemental Data S4) and was then assessed in the validation step.

\section{Validation step: diagnostic accuracy of histological and virological markers for a positive diagnosis of Merkel cell carcinoma}

After excluding the 30 cases used in the preliminary step, the performance of markers was assessed by using the identified thresholds/categories. Comparison of immunohistochemical and virological features between Merkel cell carcinoma and neuroendocrine carcinoma cases is in Table 1 and representative illustrations are in Fig. 2.

All markers showed significant differential expression between Merkel cell carcinomas and neuroendocrine carcinomas (Fisher's exact test: $p<1 \times 10^{-5}$ ), except PAX5 ( $p$ $=0.9$ ). Positive likelihood ratio $>10$, considered to provide substantial benefit for diagnostic accuracy [33], was observed for three index tests: detection of NF, SATB2, and Merkel cell polyomavirus (Table 1). Dot-pattern NF expression (Fig. 2c) was observed in $75 \%$ of Merkel cell carcinoma cases and only one small-cell bladder neuroendocrine carcinoma case (positive likelihood ratio: 44.4). In all, $64 \%$ of Merkel cell carcinoma cases and only one small-cell gallbladder neuroendocrine carcinoma case (positive likelihood ratio: 36.6) showed high and diffuse SATB2 expression (score 2) (Fig. 2d). However, both Merkel cell carcinoma (24\%) and neuroendocrine carcinoma (18\%) cases showed low and heterogenous SATB2 expression (score 1). Merkel cell polyomavirus detection, both by immunochemistry (LTAg expression) and real-time PCR, demonstrated high specificity for Merkel cell carcinoma. With the cutoff determined in the preliminary set, real-time PCR (positive likelihood ratio: 28.2) was more sensitive ( $83 \%$ of positive Merkel cell carcinoma cases) than immunohistochemistry with LTAg (64\% positivity) $\left(p<1 \times 10^{-3}\right)$ (Table 1$)$. In contrast, LTAg immunohistochemistry was specific for Merkel cell carcinoma, whereas real-time PCR also detected Merkel cell polyomavirus above the pre-specified threshold in two extracutaneous neuroendocrine carcinoma cases: one large-cell colic case (Merkel cell polyomavirus copies/cell =4) and one small-cell bladder case previously described as NF-positive (Merkel cell polyomavirus copies/cell =30). Neither of these two neuroendocrine carcinoma cases stained positive for LTAg, CK20, or SATB2 on immunohistochemistry.

\section{NF and SATB2 expression and Merkel cell polyomavirus detection in Merkel cell carcinoma variants}

Because Merkel cell carcinoma phenotypic variants (CK20negative and Merkel cell carcinoma without a skin primary tumor) are the most challenging Merkel cell carcinoma diagnoses in current practice, SATB2 and NF expression and Merkel cell polyomavirus detection were compared between classical cutaneous Merkel cell carcinoma cases and such variants (Fig. 1 and Table 2). Regarding Merkel cell carcinomas of the lymph node without a skin primary tumor, dot pattern NF expression, high and diffuse SATB2 expression (score 2), and Merkel cell polyomavirus detection above the pre-specified threshold were observed in $85 \%, 74 \%$, and $93 \%$ of cases, respectively, and the diagnostic performance of these markers was similar to that for cutaneous Merkel cell carcinomas (Table 2) (positive likelihood ratios in Merkel cell carcinoma without a skin primary tumor: 51 (95\% CI: 7-357), 41.8 (95\% CI: 6-299), and 32 (95\% CI: 8-124) respectively).

By contrast, CK20-negative Merkel cell carcinoma cases showed significantly lower dot pattern NF expression than classical Merkel cell carcinoma cases (44 vs 78\%, $p=0.03$ ) and lower, although not significantly, SATB2 (score 2) expression (37.5 vs $61 \%, p=0.25$ ) (Table 2). In total, 4 (50\%) and 7 (78\%) CK20-negative Merkel cell carcinoma cases featured LTAg and Merkel cell polyomavirus genome detection, respectively (Table 2 ).

\section{SATB2 and NF expression and Merkel cell polyomavirus detection in the CK20-negative neuroendocrine carcinoma setting}

Because neuroendocrine carcinoma metastasis remains the main differential diagnosis to exclude when assessing a cutaneous CK20-negative tumor, we assessed the diagnostic accuracy of our markers in the restricted CK20-negative setting (Fig. 1 and Table 3). SATB2 and NF expression and Merkel cell polyomavirus real-time PCR remained accurate tools for Merkel cell carcinoma diagnosis in this setting (positive likelihood ratio: 20, 24, and 24, respectively). Accordingly, 8/9 (89\%) CK20-negative Merkel cell carcinoma cases and only $3 / 61(5 \%)$ extracutaneous neuroendocrine carcinoma cases were positive for at least one of these markers. 
Table 1 Diagnostic accuracy of immunochemical and virological features between Merkel cell carcinoma and neuroendocrine carcinoma populations

\begin{tabular}{|c|c|c|c|c|c|c|}
\hline Marker & $\begin{array}{l}\text { Merkel cell } \\
\text { carcinoma } \\
(n=103)\end{array}$ & $\begin{array}{l}\text { Neuroendocrine } \\
\text { carcinoma } \\
(n=70)\end{array}$ & $p^{\mathrm{a}}$ & $\begin{array}{l}\text { Sensitivity } \\
(95 \% \mathrm{CI})\end{array}$ & $\begin{array}{l}\text { Specificity } \\
(95 \% \mathrm{CI})\end{array}$ & $\begin{array}{l}\text { Positive } \\
\text { likelihood } \\
\text { ratio } \\
(95 \% \mathrm{CI})\end{array}$ \\
\hline Cytokeratin 20 & & & \multirow{4}{*}{$\begin{array}{l}<1 \times \\
10^{-5}\end{array}$} & \multirow{4}{*}{$\begin{array}{l}91 \% \\
(84-95)\end{array}$} & \multirow{4}{*}{$\begin{array}{l}94 \% \\
(85-98)\end{array}$} & \multirow[t]{4}{*}{$14.8(6-38)$} \\
\hline Positive & $94(91 \%)$ & $4(6 \%)$ & & & & \\
\hline Negative & $9(9 \%)$ & $61(94 \%)$ & & & & \\
\hline $\begin{array}{l}\text { Uninterpretable } \\
\text { cases }\end{array}$ & 0 & 5 & & & & \\
\hline TTF-1 & & & \multirow{4}{*}{$\begin{array}{l}<1 \times \\
10^{-5}\end{array}$} & \multirow{4}{*}{$\begin{array}{l}89 \% \\
(81-95)\end{array}$} & \multirow{4}{*}{$\begin{array}{l}57 \% \\
(44-69)\end{array}$} & \multirow{4}{*}{$\begin{array}{l}2.1 \\
(1.6-2.8)\end{array}$} \\
\hline Positive & $10(11 \%)$ & $37(57 \%)$ & & & & \\
\hline Negative & $85(89 \%)$ & $28(43 \%)$ & & & & \\
\hline $\begin{array}{l}\text { Uninterpretable } \\
\text { cases }\end{array}$ & 8 & 5 & & & & \\
\hline ATOH1 & & & \multirow{5}{*}{$\begin{array}{l}<1 \times \\
10^{-5}\end{array}$} & \multirow{5}{*}{$\begin{array}{l}68 \% \\
(58-78)\end{array}$} & \multirow{5}{*}{$\begin{array}{l}51 \% \\
(38-64)\end{array}$} & \multirow[t]{5}{*}{$1.4(1-1.9)$} \\
\hline Score 2 & $65(68 \%)$ & $29(49 \%)$ & & & & \\
\hline Score 1 & $29(31 \%)$ & $14(24 \%)$ & & & & \\
\hline Score 0 & $1(1 \%)$ & $16(27 \%)$ & & & & \\
\hline $\begin{array}{l}\text { Uninterpretable } \\
\text { cases }\end{array}$ & 8 & 11 & & & & \\
\hline NF & & & \multirow{5}{*}{$\begin{array}{l}<1 \times \\
10^{-5}\end{array}$} & \multirow{5}{*}{$\begin{array}{l}75 \% \\
(65-83)\end{array}$} & \multirow{5}{*}{$\begin{array}{l}98 \% \\
(91-100)\end{array}$} & \multirow{5}{*}{$\begin{array}{l}\mathbf{4 4 . 4} \\
(6-311)\end{array}$} \\
\hline Dot & $73(75 \%)$ & $1(2 \%)$ & & & & \\
\hline Diffus & 0 & $2(2 \%)$ & & & & \\
\hline Negative & $24(25 \%)$ & $56(96 \%)$ & & & & \\
\hline $\begin{array}{l}\text { Uninterpretable } \\
\text { cases }\end{array}$ & 6 & 11 & & & & \\
\hline SATB2 & & & \multirow{5}{*}{$\begin{array}{l}<1 \times \\
10^{-5}\end{array}$} & \multirow{5}{*}{$\begin{array}{l}64 \% \\
(54-74)\end{array}$} & \multirow{5}{*}{$\begin{array}{l}98 \% \\
(91-100)\end{array}$} & \multirow{5}{*}{$\begin{array}{l}\mathbf{3 6 . 6} \\
(5-257)\end{array}$} \\
\hline Score 2 & $63(64 \%)$ & $1(2 \%)$ & & & & \\
\hline Score 1 & $23(24 \%)$ & $10(18 \%)$ & & & & \\
\hline Score 0 & $12(12 \%)$ & $46(80 \%)$ & & & & \\
\hline $\begin{array}{l}\text { Uninterpretable } \\
\text { cases }\end{array}$ & 5 & 13 & & & & \\
\hline CD99 & & & \multirow{5}{*}{$\begin{array}{l}< \\
1 \times \\
10^{-5}\end{array}$} & \multirow{5}{*}{$\begin{array}{l}65 \% \\
(55-74)\end{array}$} & \multirow{5}{*}{$\begin{array}{l}83 \% \\
(66-93)\end{array}$} & \multirow[t]{5}{*}{$3.8(2-8)$} \\
\hline Dot & $63(65 \%)$ & $6(17 \%)$ & & & & \\
\hline Diffus & $19(20 \%)$ & $21(60 \%)$ & & & & \\
\hline Negative & $15(15 \%)$ & $8(23 \%)$ & & & & \\
\hline $\begin{array}{l}\text { Uninterpretable } \\
\text { cases }\end{array}$ & 6 & 35 & & & & \\
\hline PAX5 & & & \multirow[t]{5}{*}{0.9} & \multirow{5}{*}{$\begin{array}{l}23 \% \\
(15-33)\end{array}$} & $76 \%$ & \\
\hline Score 2 & $4(5 \%)$ & $3(5 \%)$ & & & & $(0.2-3.4)$ \\
\hline Score 1 & $18(18 \%)$ & $11(19 \%)$ & & & & \\
\hline Score 0 & $74(77 \%)$ & $43(76 \%)$ & & & & \\
\hline $\begin{array}{l}\text { Uninterpretable } \\
\text { cases }\end{array}$ & 7 & 13 & & & & \\
\hline $\mathrm{TdT}$ & & & $<$ & $20 \%$ & $100 \%$ & - \\
\hline Positive & $20(20 \%)$ & 0 & $\begin{array}{l}1 \times \\
10^{-5}\end{array}$ & $(13-30)$ & $(94-100)$ & \\
\hline Negative & $78(80 \%)$ & $58(100 \%)$ & & & & \\
\hline $\begin{array}{l}\text { Uninterpretable } \\
\text { cases }\end{array}$ & 5 & 12 & & & & \\
\hline MUC1 & & & & & & $4.5(2-11)$ \\
\hline
\end{tabular}


Table 1 (continued)

\begin{tabular}{|c|c|c|c|c|c|c|}
\hline Marker & $\begin{array}{l}\text { Merkel cell } \\
\text { carcinoma } \\
(n=103)\end{array}$ & $\begin{array}{l}\text { Neuroendocrine } \\
\text { carcinoma } \\
(n=70)\end{array}$ & $p^{\mathrm{a}}$ & $\begin{array}{l}\text { Sensitivity } \\
(95 \% \mathrm{CI})\end{array}$ & $\begin{array}{l}\text { Specificity } \\
(95 \% \mathrm{CI})\end{array}$ & $\begin{array}{l}\text { Positive } \\
\text { likelihood } \\
\text { ratio } \\
(95 \% \mathrm{CI})\end{array}$ \\
\hline $\begin{array}{l}\text { Score } 2 \\
\text { Score } 1\end{array}$ & $\begin{array}{l}45(48 \%) \\
26(28 \%)\end{array}$ & $\begin{array}{l}6(10 \%) \\
44(73 \%)\end{array}$ & \multirow{3}{*}{$\begin{array}{l}< \\
1 \times \\
10^{-5}\end{array}$} & \multirow[t]{3}{*}{$\begin{array}{l}48 \% \\
(37-58)\end{array}$} & \multirow[t]{3}{*}{$\begin{array}{l}90 \% \\
(79-96)\end{array}$} & \\
\hline Score 0 & $23(24 \%)$ & $10(17 \%)$ & & & & \\
\hline $\begin{array}{l}\text { Uninterpretable } \\
\text { cases }\end{array}$ & 9 & 10 & & & & \\
\hline LTAg (CM2B4) & & & \multirow{4}{*}{$\begin{array}{l}< \\
1 \times \\
10^{-5}\end{array}$} & \multirow{4}{*}{$\begin{array}{l}64 \% \\
(53-73)\end{array}$} & \multirow{4}{*}{$\begin{array}{l}100 \% \\
(94-100)\end{array}$} & \multirow[t]{4}{*}{ - } \\
\hline Positive & $60(64 \%)$ & 0 & & & & \\
\hline Negative & $34(36 \%)$ & $60(100 \%)$ & & & & \\
\hline $\begin{array}{l}\text { Uninterpretable } \\
\text { cases }\end{array}$ & 9 & 10 & & & & \\
\hline $\begin{array}{l}\text { Merkel cell } \\
\text { polyomavirus qPCR }\end{array}$ & & & \multirow{4}{*}{$\begin{array}{l}< \\
1 \times \\
10^{-5}\end{array}$} & \multirow[t]{4}{*}{$\begin{array}{l}83 \% \\
(74-90)\end{array}$} & \multirow[t]{4}{*}{$\begin{array}{l}97 \% \\
(90-100)\end{array}$} & \multirow[t]{4}{*}{$\begin{array}{l}\mathbf{2 8 . 2} \\
(7-111)\end{array}$} \\
\hline Positive & $83(83 \%)$ & $2(3 \%)$ & & & & \\
\hline Negative & $17(17 \%)$ & $66(97 \%)$ & & & & \\
\hline $\begin{array}{l}\text { Uninterpretable } \\
\text { cases }\end{array}$ & 3 & 2 & & & & \\
\hline
\end{tabular}

Results are expressed in percentages of interpretable cases

Positive likelihood could not be determined for TdT and LTAg expression. Positive likelihood ratio > 10 indicated in bold were considered for further analysis. Merkel cell polyomavirus positive or negative status were determined by the Allred score and predeterminated cutoff (Merkel cell polyomavirus copies/cell $>1.2$ ) for immunochemistry and qPCR, respectively

ATOH1 atonal homolog 1, CK20 cytokeratin 20, LTAg large T antigen, MUC1 cell surface-associated mucin 1, NF neurofilament, PAX5 paired box protein 5, $q P C R$ quantitative PCR, SATB2 special AT-rich sequence-binding protein 2, TdT terminal deoxynucleotidyl transferase, TTF-1 thyroid transcription factor 1

${ }^{a}$ Fisher's exact test

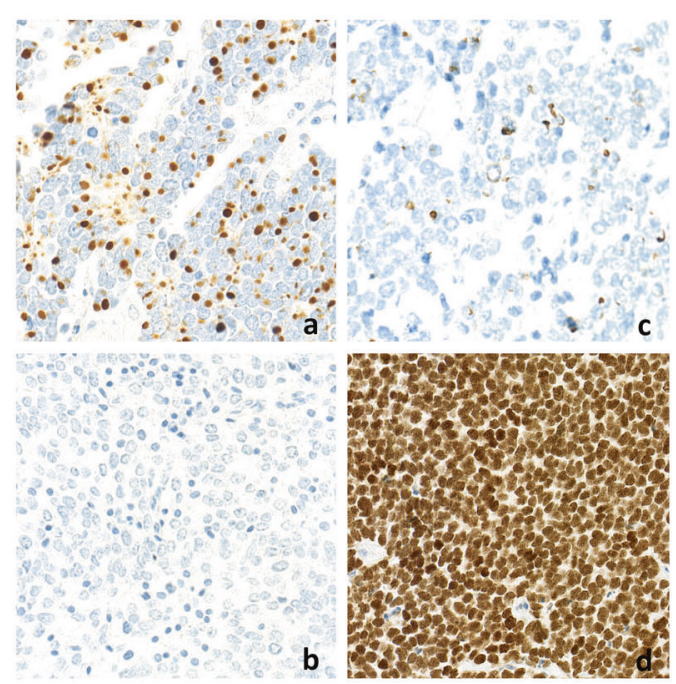

Fig. 2 Representative immunohistochemical staining of Merkel cell carcinoma tissue sections. a CK20 expression with paranuclear dot pattern, b lack of TTF-1 expression; c NF expression with a dot pattern; d high and diffuse nuclear expression of SATB2; e high and diffuse nuclear expression of ATOH1; $\mathbf{f}$ high and diffuse nuclear
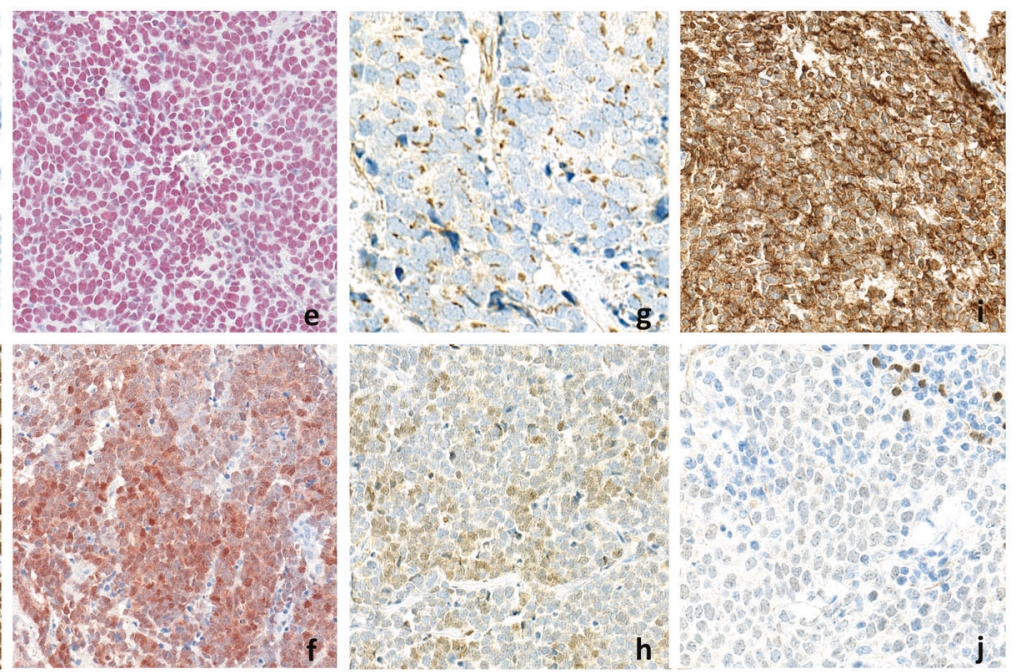

expression of LTAg (Allred score =8); g CD99 expression with paranuclear dot pattern; h low TdT expression; I high and diffuse expression of MUC1; j low expression of PAX5 with intratumor lymphocytes as positive controls 
Table 2 Detection of the MCC markers NF, SATB2, and Merkel cell polyomavirus in classical MCC compared with MCC phenotypic variants

\begin{tabular}{|c|c|c|c|}
\hline \multirow[t]{2}{*}{ Marker } & \multirow{2}{*}{$\begin{array}{l}\text { Classical } \\
\text { Merkel cell } \\
\text { carcinoma } \\
\text { cases } \\
\text { Cutaneous } \\
\text { CK20 }(+) \\
\text { cases }(n=68)\end{array}$} & \multicolumn{2}{|c|}{ Merkel cell carcinoma variants } \\
\hline & & $\begin{array}{l}\text { Cutaneous } \\
\text { CK20 }(-) \\
\text { cases }(n=9)\end{array}$ & $\begin{array}{l}\text { Nodal cases } \\
\text { without a skin } \\
\text { primary } \\
\text { tumor } \\
(n=15)\end{array}$ \\
\hline \multicolumn{4}{|l|}{ CK20 } \\
\hline Positive & $68(100 \%)$ & 0 & $15(100 \%)$ \\
\hline Negative & 0 & $9(100 \%)$ & 0 \\
\hline $\begin{array}{l}\text { Uninterpretable } \\
\text { cases }\end{array}$ & 0 & 0 & 0 \\
\hline \multicolumn{4}{|l|}{ NF } \\
\hline Dot & $50(78 \%)$ & $4(44 \%)$ & $12(85 \%)$ \\
\hline Diffuse & 0 & 0 & 0 \\
\hline Negative & $14(22 \%)$ & $5(56 \%)$ & $2(15 \%)$ \\
\hline $\begin{array}{l}\text { Uninterpretable } \\
\text { cases }\end{array}$ & 4 & 0 & 1 \\
\hline \multicolumn{4}{|l|}{ SATB2 } \\
\hline Score 2 & $39(61 \%)$ & $3(37.5 \%)$ & $11(74 \%)$ \\
\hline Score 1 & $19(30 \%)$ & $2(25 \%)$ & $2(13 \%)$ \\
\hline Score 0 & $6(9 \%)$ & $3(37.5 \%)$ & $2(13 \%)$ \\
\hline $\begin{array}{l}\text { Uninterpretable } \\
\text { cases }\end{array}$ & 4 & 1 & 0 \\
\hline \multicolumn{4}{|l|}{ LTAg (CM2B4) } \\
\hline Positive & $38(62 \%)$ & $4(50 \%)$ & $10(71 \%)$ \\
\hline Negative & $23(38 \%)$ & $4(50 \%)$ & $4(29 \%)$ \\
\hline $\begin{array}{l}\text { Uninterpretable } \\
\text { cases }\end{array}$ & 7 & 1 & 1 \\
\hline \multicolumn{4}{|c|}{ Merkel cell polyomavirus qPCR } \\
\hline Positive & $54(82 \%)$ & $7(78 \%)$ & $13(93 \%)$ \\
\hline Negative & $12(18 \%)$ & $2(22 \%)$ & $1(7 \%)$ \\
\hline $\begin{array}{l}\text { Uninterpretable } \\
\text { cases }\end{array}$ & 2 & 0 & 1 \\
\hline
\end{tabular}

The results are expressed in percentages of interpretable cases

Merkel cell polyomavirus positive or negative status were determined by the Allred score and predeterminated cutoff (Merkel cell polyomavirus copies/cell $>1.2$ ) for immunochemistry and qPCR, respectively

CK20 cytokeratin 20, LTAg large T antigen, NF neurofilament, $q P C R$ quantitative PCR, SATB2 special AT-rich sequence-binding protein 2

\section{Discussion}

The diagnosis of Merkel cell carcinoma is mainly based on the association of clinical data, microscopic features of high-grade neuroendocrine carcinoma, and CK20 positivity and TTF-1 negativity on immunohistochemistry. In current practice, distinguishing between Merkel cell carcinoma and metastasis from a non-cutaneous neuroendocrine carcinomas may be challenging with some phenotypic variants of Merkel cell carcinoma, notably Merkel cell carcinoma without a skin primary tumor $[12,34]$ and CK20-negative cases $[8,9]$ (14 and $8 \%$ of our cases, respectively). The aim of this study was to evaluate the accuracy of additional markers in a large cohort of Merkel cell carcinoma cases in comparison with extracutaneous neuroendocrine carcinomas. Our results suggest that NF and SATB2 immunohistochemical expression as well as Merkel cell polyomavirus real-time PCR detection are accurate tools to distinguish Merkel cell carcinoma from extracutaneous neuroendocrine carcinoma metastasis. Regarding Merkel cell carcinoma variants, which remain the most challenging diagnostic issue, Merkel cell carcinoma of the lymph node without a skin primary tumor cases had frequent expression of these three markers $(85,74$ and 93\%, respectively). For CK20negative cases, NF and SATB2 were less frequently expressed; however, the three markers still retained high diagnostic accuracy in this setting. Accordingly, at least one of these markers was positive in $89 \%$ of CK20-negative Merkel cell carcinoma cases and only 5\% of extracutaneous CK20-negative neuroendocrine carcinoma cases.

A range of markers was previously reported to be expressed in Merkel cell carcinoma, but their diagnostic accuracy had not been compared to neuroendocrine carcinoma, which remains the main differential diagnosis of Merkel cell carcinoma.

In 1878, Sigmund Friedrich Merkel identified a new cellular type of cells located in the basal layer of the epidermis that frequently aggregated to form a specialized structure involved in proprioception - the touch dome [35]. Indeed, Merkel cells harbor a mechanoreceptor phenotype, form synaptic-like structures with afferent terminals [36] and express some neural-cell markers such as NF [37]. NF is frequently observed in Merkel cell carcinoma [14, 15], and we found that the "dot pattern" of NF expression is sensitive (75\%) and highly specific (98\%) for a positive diagnosis of Merkel cell carcinoma in the setting of neuroendocrine carcinoma.

SATB2 seems to be another useful marker of Merkel cell carcinoma [17]. SATB2 is a nuclear matrix-associated protein involved in chromatin remodeling and gene regulation [38]. In the skin, SATB2 expression is restricted to Merkel cells [17]. In extracutaneous tissues, SATB2 is involved in cell differentiation of neuronal [39] and colonic cells [40] and drives CK20 expression [39] in this latter, so it could also contribute to the Merkel cell phenotype in the skin. Recently Fukuhara et al. [17] reported SATB2 as a specific marker of Merkel cell carcinoma in comparison with 37 cutaneous tumors. In the present study, we confirmed the high specificity (98\%) of SATB2 for the diagnosis of Merkel cell carcinoma among neuroendocrine 
Table 3 Diagnostic accuracy of NF (dot pattern) and SATB2

(score 2) expression and Merkel cell polyomavirus detection (Merkel cell polyomavirus copie/cell > 1.2) for a positive diagnosis of Merkel cell carcinoma in the CK20-negative neuroendocrine carcinoma setting (70 cases)

\begin{tabular}{|c|c|c|c|c|c|}
\hline Index test & $\begin{array}{l}\text { No. of CK20 } \\
(-) \text { Merkel cell } \\
\text { carcinomas } \\
(n=9)\end{array}$ & $\begin{array}{l}\text { No. of CK20(-) } \\
\text { neuroendocrine } \\
\text { carcinomas } \\
(n=61)\end{array}$ & $\begin{array}{l}\text { Sensitivity } \\
(95 \% \mathrm{CI})\end{array}$ & $\begin{array}{l}\text { Specificity } \\
(95 \% \mathrm{CI})\end{array}$ & $\begin{array}{l}\text { Positive } \\
\text { likelihood } \\
\text { ratio } \\
(95 \% \mathrm{CI})\end{array}$ \\
\hline $\mathrm{NF}$ & & & $44(14-79)$ & $98(90-100)$ & $24(3-191)$ \\
\hline Dot pattern & $4(44 \%)$ & $1(2 \%)$ & & & \\
\hline Other & $5(56 \%)$ & $53(98 \%)$ & & & \\
\hline $\begin{array}{l}\text { Uninterpretable } \\
\text { cases }\end{array}$ & 0 & 7 & & & \\
\hline SATB2 & & & 37.5 & $98(90-100)$ & $20(2-168)$ \\
\hline Score 2 & $3(37.5 \%)$ & $1(2 \%)$ & $(8.52-75)$ & & \\
\hline Score $0-1$ & $5(62.5 \%)$ & $52(98 \%)$ & & & \\
\hline $\begin{array}{l}\text { Uninterpretable } \\
\text { cases }\end{array}$ & 1 & 8 & & & \\
\hline $\begin{array}{l}\text { Merkel cell } \\
\text { polyomavirus qPCR }\end{array}$ & & & 78 (40-97) & $97(89-100)$ & $24(6-97)$ \\
\hline Positive & $7(78 \%)$ & $2(3 \%)$ & & & \\
\hline Negative & $2(22 \%)$ & $59(97 \%)$ & & & \\
\hline $\begin{array}{l}\text { Uninterpretable } \\
\text { case }\end{array}$ & 0 & 0 & & & \\
\hline
\end{tabular}

The results are expressed in percentages of interpretable cases

Nine CK20-negative Merkel cell carcinoma and 61 CK20-negative neuroendocrine cases were analyzed. Merkel cell polyomavirus positive or negative status were determined by the Allred score and predeterminated cutoff (Merkel cell polyomavirus copies/cell >1.2) for immunochemistry and qPCR, respectively

$N F$ neurofilament, SATB2 special AT-rich sequence-binding protein 2 carcinoma cases. Of note, in the spectrum of neuroendocrine tumors, well-differentiated tumors of the lower digestive tract showed SATB2 expression [41] and could be easily distinguished from Merkel cell carcinoma on morphology and tumor location.

ATOH1 did not show high diagnostic performance in our study. In mice, ATOH1 have been found the most important transcription factor driving Merkel cell differentiation [42]. In 2010, Heiskala et al. investigated ATOH1 expression in neuroendocrine neoplasia and observed ATOH1 positivity in Merkel cell carcinoma and in tumors of the digestive tract and parathyroid [43]. Accordingly, we found ATOH1 positivity in our extracutaneous neuroendocrine carcinoma cases, which rules out its use for Merkel cell carcinoma diagnosis. Similarly, other markers such as TdT and PAX5, CD99 or MUC1 did not seem relevant for Merkel cell carcinoma diagnosis because they were expressed in a few Merkel cell carcinoma cases and/or were expressed in other neuroendocrine carcinoma cases. Of note, INSM1 (Insulinoma-associated protein 1) was recently identified as a performant marker to confirm the neuroendocrine nature of Merkel cell carcinoma [44, 45]. Due to its lack of abilities to distinguish Merkel cell carcinoma from other neuroendocrine carcinoma cases, this marker was not tested in the present study but still remains an useful tool in combination with CK20, SATB2, NF, and Merkel cell polyomavirus detection to confirm Merkel cell carcinoma diagnosis in current practice.

Assessing Merkel cell polyomavirus DNA as a marker of Merkel cell carcinoma has previously been debated. Merkel cell polyomavirus has been detected in a large range of nonMerkel cell carcinoma neoplasia [46] because this virus is ubiquitous in the papillary dermis of healthy people [47, 48] and can be detected in the environment if sufficiently sensitive methods are applied [49]. In a diagnosis context, the main issue is to distinguish Merkel cell polyomavirus episomal virus, which can be detected at very low levels in the skin of healthy people [48], from an integrated virus detected at higher levels, in at least each cell of Merkel cell polyomavirus-positive Merkel cell carcinomas. Thus, realtime PCR seems a relevant tool in this setting. Also, we determined an optimal threshold of Merkel cell polyomavirus load that allowed for accurately differentiating Merkel cell carcinomas from $100 \%$ of non-Merkel cell carcinoma cutaneous tumors included as negative controls and from $97 \%$ of extracutaneous neuroendocrine carcinoma tumors. Detection of Merkel cell polyomavirus-LTAg by immunochemistry with the commercial clone CM2B4 has recently been found have the best overall accuracy for classifying Merkel cell carcinomas as virus-positive or -negative [22]. However, with this technique, we and others [50] identified only $64 \%$ of viropositivity among Merkel 
cell carcinoma cases as compared with $83 \%$ with molecular procedures [2]. Lower sensitivity of this antibody as compared with another non-commercial antibody was previously emphasized [23]. Of note, real-time PCR still detected Merkel cell polyomavirus in two neuroendocrine carcinoma cases, including a bladder neuroendocrine carcinoma tumor that also stained positive for the Merkel cell carcinoma marker NF. Merkel cell polyomavirus has been suggested to be involved as a carcinogenic agent in bladder carcinoma [51]. However, further investigations are needed to confirm the existence of Merkel cell polyomavirus ( + ) primary tumors of the bladder.

After having identified the most accurate markers in the overall Merkel cell carcinoma cases, we assessed them in the setting of difficult-to-diagnose cases, such as Merkel cell carcinomas without a skin primary tumor or CK20-negative Merkel cell carcinomas, which are the main challenge in practice. Indeed, Merkel cell carcinoma of the lymph node without a skin primary tumor, which represented $14 \%$ of our Merkel cell carcinoma cohort, can be misdiagnosed as lymph node metastases from other neuroendocrine carcinoma, with detrimental consequences on disease management. In a previous study, we reported that Merkel cell carcinoma without a skin primary tumor shared similar morphological and phenotypical features with cutaneous Merkel cell carcinoma but was accurately distinguished from other superficial neuroendocrine carcinoma lymph node metastasis by a spectrum of clinical, histological and virological criteria summarized as the ELECTHIP criteria (Elderly: $\geq 70$ years, Location: inguinal or parotid, Extent restricted to the lymph node area, CK20 positivity, TTF-1 negativity, Histological type: small cell neuroendocrine carcinoma, Polyomavirus detection) [13]. Accordingly, NF and SATB2, the relevant immunohistochemical Merkel cell carcinoma markers assessed in the current study, were expressed in Merkel cell carcinoma without a skin primary tumor cases at similar levels as cutaneous primary Merkel cell carcinoma cases (NF, dot staining: 85\%; SATB2 positivity, score 2: 74\%) and therefore could be used as additional tools to confirm the Merkel cell carcinoma without a skin primary tumor diagnosis.

In contrast, we identified CK20-negative Merkel cell carcinoma cases ( $8 \%$ of the cases) as a distinct subgroup with decreased frequency of NF and SATB2 expression ( $44 \%$ and $37.5 \%$ of positive cases, respectively). Only few data are available on the phenotype of this Merkel cell carcinoma subset. TTF-1 negativity has been confirmed in this population [8, 52] and NF expression was previously detected in two of three investigated cases [8]. Although CK7 positivity has been observed [52], it was an infrequent finding in another study [8] and in our study ( $n=0 / 9$ cases, data not shown). In 2015, Miner et al. [8] reported $77 \%$ Merkel cell polyomavirus-negativity among CK20-negative
Merkel cell carcinoma cases. Additional analysis [9] revealed a high level of chromosomal anomalies and frequent somatic mutations with a UV signature, which suggested non-viral, UV-induced oncogenesis for CK20negative cases and ruled out the relevance of Merkel cell polyomavirus detection as a diagnostic tool for this Merkel cell carcinoma subset. By contrast, in our study, Merkel cell polyomavirus detection was the most sensitive tool for Merkel cell carcinoma diagnosis $(78 \%$ of real-time PCR positivity above predefined threshold-7/9 CK20-negative cases). However, considering that Merkel cell polyomavirus detection methods are only available in a few specialized centers and because of the widespread availability of SATB2 and NF markers, a first immunohistochemical investigation of NF and SATB2 status, which conferred a high positive likelihood ratio in this setting (24 and 20, respectively), followed by Merkel cell polyomavirus detection in a specialized center may represent an alternative approach in current practice.

To conclude, we provide evidence of NF and SATB2 protein expression and Merkel cell polyomavirus DNA detection as three relevant additional accurate markers for Merkel cell carcinoma. Moreover, regarding these three criteria, we demonstrate that Merkel cell carcinoma without a skin primary tumor shares a similar phenotype with other Merkel cell carcinoma, whereas CK20-negative Merkel cell carcinoma constitutes a distinct group, which nevertheless can be distinguished from other neuroendocrine carcinoma cases by using NF, SATB2 and Merkel cell polyomavirus detection.

Acknowledgements We sincerely thank Dr. C. Barbet, Dr. A.M. Bergemer-Fouquet, Dr. C. Collin, R. Gibon, Dr. M.C. Machet, Dr. A. de Muret, A.S. Neumann, Dr. I. Orain, Dr. C. Rousselot, I. Rüddel, and B. Sevin for their help and contributions.

Funding Fond de recherche de la société française de Pathologie 2016. Fondation ARC: "Aide individuelle 2017"

\section{Compliance with ethical standards}

Conflict of interest The authors declare that they have no conflict of interest.

Institutional review board The local Ethics Committee in Human Research of Tours (France) approved the study (no. ID RCB2009A01056-51)

\section{References}

1. LeBoit PE, World Health Organization. Pathology and genetics of skin tumours. Lyon: IARC Press, 2007.

2. Feng H, Shuda M, Chang Y, et al. Clonal integration of a polyomavirus in human Merkel cell carcinoma. Science. 2008;319: 1096-100.

3. Shuda M, Guastafierro A, Geng X, et al. Merkel cell polyomavirus small $\mathrm{T}$ antigen induces cancer and embryonic merkel cell 
proliferation in a transgenic mouse model. PloS ONE. 2015;10: e0142329.

4. Touzé A, Le Bidre E, Laude H, et al. High levels of antibodies against merkel cell polyomavirus identify a subset of patients with merkel cell carcinoma with better clinical outcome. J Clin Oncol. 2011;29:1612-9.

5. Houben R, Adam C, Baeurle A, et al. An intact retinoblastoma protein-binding site in Merkel cell polyomavirus large $\mathrm{T}$ antigen is required for promoting growth of Merkel cell carcinoma cells. Int J Cancer. 2012;130:847-56.

6. Verhaegen ME, Mangelberger D, Harms PW, et al. Merkel cell polyomavirus small $\mathrm{T}$ antigen initiates merkel cell carcinoma-like tumor development in mice. Cancer Res. 2017;77:3151-7.

7. Cheuk W, Kwan MY, Suster S, et al. Immunostaining for thyroid transcription factor 1 and cytokeratin 20 aids the distinction of small cell carcinoma from Merkel cell carcinoma, but not pulmonary from extrapulmonary small cell carcinomas. Arch Pathol Lab Med. 2001;125:228-31.

8. Miner AG, Patel RM, Wilson DA, et al. Cytokeratin 20-negative Merkel cell carcinoma is infrequently associated with the Merkel cell polyomavirus. Mod Pathol. 2015;28:498-504.

9. Harms PW, Collie AMB, Hovelson DH, et al. Next generation sequencing of Cytokeratin 20-negative Merkel cell carcinoma reveals ultraviolet-signature mutations and recurrent TP53 and RB1 inactivation. Mod Pathol. 2016;29:240-8.

10. Reddi DM, Puri PK. Expression of focal TTF-1 expression in a case of CK7/CK20-positive Merkel cell carcinoma. J Cutan Pathol. 2013;40:431-3.

11. Nassar H, Albores-Saavedra J, Klimstra DS. High-grade neuroendocrine carcinoma of the ampulla of vater: a clinicopathologic and immunohistochemical analysis of 14 cases. Am J Surg Pathol. 2005;29:588-94.

12. Pan Z, Chen Y-Y, Wu X, et al. Merkel cell carcinoma of lymph node with unknown primary has a significantly lower association with Merkel cell polyomavirus than its cutaneous counterpart. Mod Pathol. 2014;27:1182-92.

13. Kervarrec T, Zaragoza J, Gaboriaud P, et al. Differentiating Merkel cell carcinoma of lymph nodes without a detectable primary skin tumor from other metastatic neuroendocrine carcinomas: the ELECTHIP criteria. J Am Acad Dermatol. 2018;78:964-72.

14. McCalmont TH. Paranuclear dots of neurofilament reliably identify Merkel cell carcinoma. J Cutan Pathol. 2010;37:821-3.

15. Schmidt U, Müller U, Metz KA, et al. Cytokeratin and neurofilament protein staining in Merkel cell carcinoma of the small cell type and small cell carcinoma of the lung. Am J Dermatopathol. 1998;20:346-51.

16. Gambichler T, Mohtezebsade S, Wieland U, et al. Prognostic relevance of high atonal homolog-1 expression in Merkel cell carcinoma. J Cancer Res Clin Oncol. 2016;143:43-9.

17. Fukuhara M, Agnarsdóttir M, Edqvist P-H, et al. SATB2 is expressed in Merkel cell carcinoma. Arch Dermatol Res. 2016;308:449-54.

18. Kolhe R, Reid MD, Lee JR, et al. Immunohistochemical expression of PAX5 and TdT by Merkel cell carcinoma and pulmonary small cell carcinoma: a potential diagnostic pitfall but useful discriminatory marker. Int J Clin Exp Pathol. 2013;6:142-7.

19. Zur Hausen A, Rennspiess D, Winnepenninckx V, et al. Early Bcell differentiation in Merkel cell carcinomas: clues to cellular ancestry. Cancer Res. 2013;73:4982-7.

20. Rajagopalan A, Browning D, Salama S. CD99 expression in Merkel cell carcinoma: a case series with an unusual paranuclear dot-like staining pattern. J Cutan Pathol. 2013;40:19-24.

21. Fernandez-Flores A, Suarez-Peñaranda JM. Expression of MUC1 by Merkel cell carcinoma is not dependent on merkel cell polyomavirus infection. Appl Immunohistochem Mol Morphol. 2016;24:e9-10.

22. Moshiri AS, Doumani R, Yelistratova L, et al. Polyomavirusnegative Merkel cell carcinoma: a more aggressive subtype based on analysis of 282 cases using multimodal tumor virus detection. J Invest Dermatol. 2017;137:819-27.

23. Rodig SJ, Cheng J, Wardzala J, et al. Improved detection suggests all Merkel cell carcinomas harbor Merkel polyomavirus. J Clin Invest. 2012;122:4645-53.

24. Gardair C, Samimi M, Touzé A, et al. Somatostatin receptors $2 \mathrm{~A}$ and 5 are expressed in Merkel cell carcinoma with no association with disease severity. Neuroendocrinology. 2015;101:223-35.

25. Kervarrec T, Gaboriaud P, Berthon P, et al. Merkel cell carcinomas infiltrated with $\mathrm{CD} 33+$ myeloid cells and CD8+T cells are associated with improved outcome. J Am Acad Dermatol. 2018;78:973-82.

26. Bosman FT, World Health Organization. WHO classification of tumours of the digestive system. Lyon: IARC Press, 2010.

27. Travis WD, World Health Organization. Pathology and genetics of tumours of the lung, pleura, thymus and heart. Lyon: IARC Press, 2015.

28. Bossuyt PM, Reitsma JB, Bruns DE, et al. STARD 2015: an updated list of essential items for reporting diagnostic accuracy studies. BMJ. 2015;351:h5527.

29. Asgari MM, Sokil MM, Warton EM, et al. Effect of host, tumor, diagnostic, and treatment variables on outcomes in a large cohort with Merkel cell carcinoma. JAMA Dermatol. 2014;150:716-23.

30. Renaud F, Gnemmi V, Devos P, et al. MUC1 expression in papillary thyroid carcinoma is associated with BRAF mutation and lymph node metastasis; the latter is the most important risk factor of relapse. Thyroid. 2014;24:1375-84.

31. Beer TW. Merkel cell carcinomas with CK20 negative and CK7 positive immunostaining. J Cutan Pathol. 2009;36:385-6.

32. Sidiropoulos M, Hanna W, Raphael SJ, et al. Expression of TdT in Merkel cell carcinoma and small cell lung carcinoma. Am J Clin Pathol. 2011;135:831-8.

33. Harrell FE, Califf RM, Pryor DB, et al. Evaluating the yield of medical tests. JAMA. 1982;247:2543-6.

34. Haymerle G, Fochtmann A, Kunstfeld R, et al. Management of Merkel cell carcinoma of unknown primary origin: the Vienna Medical School experience. Eur Arch OtorhinoLaryngol. 2015;272:425-9.

35. Halata Z, Grim M, Bauman KI. Friedrich Sigmund Merkel and his "Merkel cell", morphology, development, and physiology: review and new results. Anat Rec A Discov Mol Cell Evol Biol. 2003;271:225-39.

36. Nakatani M, Maksimovic S, Baba Y, et al. Mechanotransduction in epidermal Merkel cells. Pflug Arch. 2015;467:101-8.

37. Narisawa $Y$, Hashimoto $K$, Kohda H. Immunohistochemical demonstration of the expression of neurofilament proteins in Merkel cells. Acta Derm Venereol. 1994;74:441-3.

38. Zarate YA, Fish JL. SATB2-associated syndrome: mechanisms, phenotype, and practical recommendations. Am J Med Genet A. 2017;173:327-37.

39. Leone DP, Heavner WE, Ferenczi EA, et al. Satb2 regulates the differentiation of both callosal and subcerebral projection neurons in the developing cerebral cortex. Cereb Cortex 1991. 2015;25:3406-19.

40. Múnera JO, Sundaram N, Rankin SA, et al. Differentiation of human pluripotent stem cells into colonic organoids via transient activation of BMP signaling. Cell Stem Cell. 2017;21: 51-64.e6.

41. Li Z, Yuan J, Wei L, et al. SATB2 is a sensitive marker for lower gastrointestinal well-differentiated neuroendocrine tumors. Int J Clin Exp Pathol. 2015;8:7072-82. 
42. Ostrowski SM, Wright MC, Bolock AM, et al. Ectopic Atoh1 expression drives Merkel cell production in embryonic, postnatal and adult mouse epidermis. Dev Camb Engl. 2015;142:2533-44.

43. Heiskala K, Arola J, Heiskala M, et al. Expression of Reg IV and Hath1 in neuroendocrine neoplasms. Histol Histopathol. 2010;25:63-72.

44. Lilo MT, Chen Y, LeBlanc RE. INSM1 is more sensitive and interpretable than conventional immunohistochemical stains used to diagnose merkel cell carcinoma. Am J Surg Pathol. 2018.

45. Rush PS, Rosenbaum JN, Roy M, et al. Insulinoma-associated 1: a novel nuclear marker in Merkel cell carcinoma (cutaneous neuroendocrine carcinoma). J Cutan Pathol. 2018;45:129-35.

46. Rollison DE, Giuliano AR, Messina JL, et al. Case-control study of Merkel cell polyomavirus infection and cutaneous squamous cell carcinoma. Cancer Epidemiol Biomark Prev. 2012;21:74-81.

47. Liu W, Yang R, Payne AS, et al. Identifying the target cells and mechanisms of merkel cell polyomavirus infection. Cell Host Microbe. 2016;19:775-87.
48. Martel-Jantin C, Pedergnana V, Nicol JTJ, et al. Merkel cell polyomavirus infection occurs during early childhood and is transmitted between siblings. J Clin Virol. 2013;58:288-91.

49. Di Bonito P, Libera SD, Petricca S, et al. Frequent and abundant Merkel cell polyomavirus detection in urban wastewaters in Italy. Food Environ Virol. 2015;7:1-6.

50. Leroux-Kozal V, Lévêque N, Brodard V, et al. Merkel cell carcinoma: histopathologic and prognostic features according to the immunohistochemical expression of Merkel cell polyomavirus large $\mathrm{T}$ antigen correlated with viral load. Hum Pathol. 2015;46:443-53.

51. Robles C, Viscidi R, Malats N, et al. Bladder cancer and seroreactivity to BK, JC and Merkel cell polyomaviruses: the Spanish bladder cancer study. Int J Cancer. 2013;133:597-603.

52. Calder KB, Coplowitz S, Schlauder S, et al. A case series and immunophenotypic analysis of CK20-/CK7 + primary neuroendocrine carcinoma of the skin. J Cutan Pathol. 2007;34:918-23.

\section{Affiliations}

\section{Thibault Kervarrec ${ }^{1,2,3} \cdot$ Anne Tallet $^{4} \cdot$ Elodie Miquelestorena-Standley ${ }^{1} \cdot$ Roland Houben $^{3}{ }^{3} \cdot$ David Schrama $^{3}$. Thilo Gambichler ${ }^{5}$. Patricia Berthon ${ }^{2}$ - Yannick Le Corre ${ }^{6}$. Ewa Hainaut-Wierzbicka ${ }^{7}$. Francois Aubin ${ }^{8}$. Guido Bens $^{9}$ - Flore Tabareau-Delalande ${ }^{10}$. Nathalie Beneton ${ }^{11}$. Gaëlle Fromont ${ }^{12}$. Flavie Arbion ${ }^{12}$. Emmanuelle Leteurtre ${ }^{13} \cdot$ Antoine Touzé $^{2} \cdot$ Mahtab Samimi $^{2,14} \cdot$ Serge Guyétant ${ }^{1,2}$}

1 Department of Pathology, Université de Tours, CHU de Tours, Avenue de la République, 37170 Chambray-les-tours, France

2 "Biologie des infections à polyomavirus" team, UMR INRA ISP 1282, Université de Tours, 31, Avenue Monge, 37200

Tours, France

3 Department of Dermatology, Venereology and Allergology, University Hospital Würzburg, Josef-Schneider-Straße 2, 97080 Würzburg, Germany

4 Platform of Somatic Tumor Molecular Genetics, Université de Tours, CHU de Tours, Avenue de la République, 37170 Chambray-les-tours, France

5 Department of Dermatology, Venereology and Allergology, University Hospital Bochum, GudrunStraße 5, 44791 Bochum, Germany

6 Dermatology Department, LUNAM Université, CHU Angers, 4 rue Larrey, 49933 Angers, France

7 Dermatology Department, Université de Poitiers, CHU de Poitiers,
2 rue de la Milétrie, 86021 Poitiers, France

8 Dermatology Department, Université de Franche Comté, CHU Besançon, EA3181, IFR133, 2 Boulevard Fleming, 25030 Besançon, France

9 Dermatology Department, CHR d'Orléans, 14 Avenue de l'hôpital, 45100 Orléans, France

10 Department of Pathology, CHR d'Orléans, 14 Avenue de l'hôpital, 45100 Orléans, France

11 Dermatology Department, CHR Le Mans, 194 Avenue Rubillard, 72037 Le Mans Cedex 09, France

12 Department of Pathology, Université de Tours, CHU de Tours, Boulevard Tonnellé, 37044 Tours, France

13 Univ. Lille, Inserm, CHU Lille, UMR-S 1172 - JPARC - JeanPierre Aubert Research Center-, F-59000 Lille, France

14 Dermatology Department, Université de Tours, CHU de Tours, Avenue de la République, 37170 Chambray-les-tours, France 